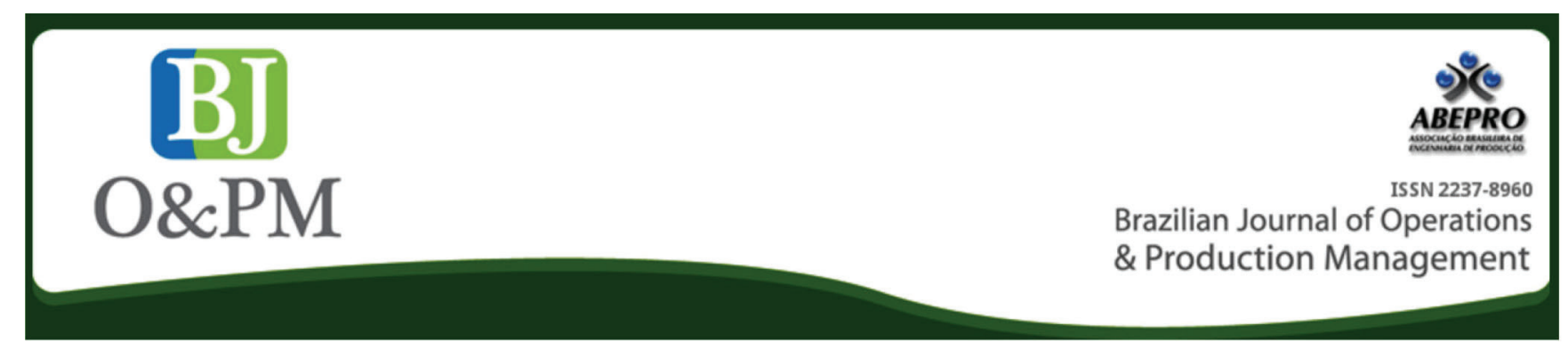

\title{
STRATEGIC ALLIANCE BETWEEN INFORMATION INTENSIVE SERVICES AND SUPPLY CHAIN INTEGRATION: IMPACT ON FIRM PERFORMANCE
}

\section{Supriyo Roy}

supriyo.online@gmail.com Birla Institute of Technology, Mesra, Jharkhand", India

\section{Biswajit Satpathy} satpathybulu@gmail.com Sambalpur University, Sambalpur, Odisha, India

\begin{abstract}
Goal: This Survey-based empirical research is aimed to theorize and assess a structural model that incorporates strategic alliance between Information Intensive Services (IIS) and Supply Chain Integration (SCI) and its impact on Firm Performance (FP), with special reference to Indian business houses.

Design / Methodology / Approach: This paper proposes a hypothesis model within the decision-making framework that offers strategic alliance tool for managers in the area of supply chain to operationalize business decisions. Samples of more than 210 primary data sets are collected from population of different industries in India by a proper sampling method and by framing questionnaires. The relationship, as proposed in the hypothesis model, is assessed empirically by using statistical techniques called Structural Equation Modeling.

Results: Practitioners may expect improved supply chain performance through strategic alliance between information intensive services and supply chain integration, as it is demanded industries in this Industry 4.0 era.

Limitations: The hypothesis framed by western standards seems to be obvious; however, considering the Indian business scenario, where the supply chain and technology of information systems are almost a new concept in most firms, this seems to be a valid area of research.

Practical Implications: Research conceptualizes and develops different dimensions of information-intensive services that offer empirical support for the adoption of proper information system to improve performance within an integrated supply chain.

Originality / Value: This survey-based empirical research will 'coordinate and highlight the issue of integration' of Enterprise Information Systems within the organizational supply chain.
\end{abstract}

Keywords: Supply Chain Intelligence, Information Intensive Services, Management Integration Practices, Industrial Performance Measurement, Structural Equation Modelling. 


\section{INTRODUCTION}

The market scenario in today's Fourth Industrial Revolution, commonly known as the 'Industry 4.0' era, is becoming increasingly competitive due to the innovation of sophisticated technology and changing customer behaviour. Business Firms are evolving into a new phase of transition based on knowledge and networks with Information Technology platform (Christopher and Holweg, 2011). Competition in the market means, in terms of improved quality, products with superior performance, cost at par, wider range of product variation and better service; all delivered simultaneously. As observed by Li et al. (2006), firms started realizing that improving efficiencies within a firm not only serve business goals, but also make the entire chain more competitive. Supplying the right product at the right price and time to the consumer is the lynchpin to competitive success (Eskandarpour et al., 2015).

Managing supply chain as originated by consultants (Houlihan, 1987) moved into academia and helped to unite procurement, operations, and distribution into a more unified discipline. Supply chain has been interpreted by various researchers in various ways since it was introduced (Craig et al., 2015). In today's business environment, 'supply chain is conceptualizing as a network for businesses' (Winter and Knemeyer, 2013) that seek to 'integrate performance measures over multiple firms rather than taking perspective of a single process'. As stated by Chen et al. (2013), 'managing supply chain has not been just dyadic; as it is said, most of the resource dependency has, but has implicitly considered - through the notion of chains - paths through a network of firms'. Today, complexity, uncertainty and variability are the pertinent characteristics of modern supply chain, which is different from its classical view, as suggested by Houlihan (1985), as he 'that viewed it as a single process; the responsibility for different segments in the supply chain is not fragmented or relegated to functional areas..., but depends on strategic decision-making'. In this study, supply is the shared objective of practically every function in the chain and is of particular strategic significance. Supply chain management calls for a different perspective on inventories that use a balancing mechanism as the last resort and, most importantly, a new approach to systems is required: 'integration rather than interfacing' (Jin et al., 2013; Ellram and Cooper, 2014).

From early 1980's, it became evident that a rigorous framework for analyzing the dynamics of supply chains and taking proper decisions would substantially improve the performance of systems. Later, in the early 1990's, these concepts began to be used to define the process of integrating suppliers, manufacturers, warehouses, and retailers. The effective management of supply chain in new business suggests seeking close and long term relationship with suppliers and customers, developing interactive relationships with each other, and working in a collaborative way (Autry et al., 2014; Xia et al., 2015). A better understanding of complex dynamics that determine the performance of supply chains has become crucial for superior performance (Chen et al., 2013). An integrative supply chain strategy integrates, as a business process, suppliers' supplier to customers' customer as well as firms to create values (Claudine and Hyland, 2015). Information Technology enabled services with Supply Chain Integration act as core constituents of this supply chain strategy. However, integration within a complex chain is not easy; it requires time, complexity, extensive survey, and exploration (Williams et al., 2013). Research shows both positive and negative results in terms of integration (Bernon et al., 2013; Chang et al., 2015). Indian business firms show less progress in the integration of business chain and supply-chain practices, while integrating with information systems show contradictory outcome in terms of firm performance (Narasimhan et al., 2010).

Market development, internationalization, and growing competitiveness have led to the emergence of the so-called Fourth Industrial Revolution and to the parallel development of both the concept of Industry 4.0 and its domain in the area of supply chain. From this result, the purpose of this study is to propose a framework that identifies relationships between information intensive services, supply-chain integration, and firm performance and to test such relationships, empirically, in terms of business managers' viewpoint. The relationships proposed above are somehow 'conceptual as well as basic'; however, a relevant gap exists in the application of synchronization. In the Indian scenario, where concepts of service operations started not long ago; integrating supply chain with information intensive services to improve firm performance is 'still in a nascent stage'. The paper's contribution may be framed within information systems that stipulate 'linkage between key organizational resource (integration of information) and its management as the organization's most critical performance factor'.

In the era of "Innovation and Technology Management in Industry 4.0", the transition to Industry 4.0 is challenging and sustainable, especially in the area of operations management (Szozda, 2017). In this sequel, considering all the issues above, the proposed research seeks to answer the following issue: 'gaining competitive edge through effective use of integration in supply chain and information system practices in a highly competitive environment has become increasingly complex (if not impossible) and also crucial in order to optimize the firm's operational performance'. Finally, it aims to reconcile all these conflicting results and try to explore the understanding of complex relationships within the domain of Indian business environment. 


\section{LITERATURE REVIEW}

\subsection{Strategic alliance under management integration}

supply chain management has received great deal of attention by practitioners and academicians since its inception (Li, 2005; Cai et al., 2009). Today managing supply chain is a holistic and strategic approach to integrate demand, operations, procurement and logistics processes (Podsakoff et al., 2012). Forward looking enterprises are very dynamic today. They collaborate with suppliers, customers and even with competitors. They share information aiming to create a collaborative supply chain that is capable of competing, if not leading a particular industry. Spurred by intensifying competition in global markets, most companies have been increasingly implementing supply chain and information systems practices (Bayraktar, 2009). Decision making in a highly competitive environment would thus depend on degree and quality of information (Wu et al., 2010).

Concepts of managing supply chain, as elaborated by several researchers, seeks to enhance competitive performance by closely integrating internal functions within firm and effectively linking them with external operations of suppliers, customers and other channel members (Kim, 2009). Much of the current research in this area focuses on upstream or downstream areas of the supply chain. A survey of 30 UK companies conducted by Frohlich (2002) shows three types of barriers to technology integration in supply chains: supplier, customer (manufacturer), and internal barriers. Cost is a major reason for resistance both by the suppliers and the customers and this often involves negotiation between the two parties involved in terms of IT investment and customization. Topics such as supplier's selection, success factor of strategic supplier alliances, supplier's responsiveness and buyer-supplier relationship have been discussed on the supplier's side. Supply chain decisions, as studied by Bozarth et al. (2009) and Kaufmann et al. (2014), mainly focus on downstream linkages between manufacturers and retailers. Studies relating to both upstream and downstream sides in the supply chain have been started very early, and refer to strategic relationships between supplier and customer relation practices and organizational performance (Huo et al., 2013).

Researchers have revealed the necessity for supply chain integration in order to foster Information sharing (Cai et al., 2010) and for the impact of Enterprise Resource Planning on it (Su and Yang, 2010). The effective use of ERP can have a dramatic impact on firm performance (Su and Yang, 2010). Again, some review suggests that a firm must not rely solely on information system practices for managing their operations (Gunasekaran and Ngai, 2004). Effective use of Material Requirements Planning (MRP) and Manu- facturing Resource Planning (MRP-II), coupled with proper information systems, envisages lead-time and inventory reduction (Rosenzweig et al., 2003; Williamson, 2008; Yang, 2014). Other operational systems, such as managing supplier and customer, warehousing and distribution, when integrated with ERP, help to improve product traceability and operational efficiency (Gunasekaran et al., 2004; Stock and Tatikonda, 2008).

Strategic investment by Indian firms for the development of Information Systems and services has been initiated during the middle of nineties. But, by not making significant changes in their supply chain systems and processes, many firms ultimately resulted to under-exploit information systems to their full potential. Keller et al. (2017) examined the limitations of integration of strategic tools with business modeling. The main limitations highlighted by them relate to idealizations according to environment in which the company operates, and is not designed for a deeper evaluation and validation by the organization. Therefore, an ultimately mapped business model still requires approval, seeking financial, market, customers and suppliers viabilities.

Finally, a review of the literatures related to strategic alliance between information intensive services and supply chain integration has seen a significant gap in firm performance (Flynn et al., 2010; Leuschner et al., 2013). Researchers have highlighted gaps, specifically to the absence of empirical research, clearly linking Information intensive services to supply chain integration and firm performance (Prajogo and Olhager, 2012; Ellinger et al., 2011).

\subsection{Theoretical framework}

as per Ellinger et al., 2012, expanded global competition has become the norm rather than the exception, with an unprecedented number and variety of products available in the retail market to satisfy consumer needs and desires. In $21^{\text {st }}$ century globalized scenario, markets are more transparent and informative; customer demands are being met in a more customized manner, and the nature of demand keeps increasing (Hitt, 2011). The successful implementation of effective use of integrated information systems and enabling technologies has allowed creating seamless supply chains correspondingly linkages in order to minimize poor performance of suppliers, unpredictable customer demands, and uncertain business environment (Mentzer et al., 2000; Zimmermann and Forest, 2014).

\subsubsection{Information Intensive Services}

As Information Intensive Services are being globalized, firms take advantage of the opportunities made available 
Brazilian Journal of Operations \& Production Management

Volume 16, Número 2, 2019, pp. 241-260

DOI: 10.14488/BJOPM.2019.v16.n2.a7 by the progress of IT and they correspondingly respond to the challenge of increasing global competition. Information System capabilities are defined as complex bundles of IT related resources, skills and knowledge, exercised through business processes that enable firms to coordinate activities and make use of these assets in a very meaningful way. It is complied with a bundle of integrative services under IT domain used by business managers in their respective field for the pursuit of excellence (Dale Stoel et al., 2009).

In reality, monitoring and improving the performance of supply chain in todays' technological domain has become an increasingly complex task for Indian firms as most of the companies started this practice recently. Understanding the link in between information systems and firm performance has been the subject of considerable interest to many researchers and business practitioners (DeGroote and Marx, 2013). Information integrative services within the supply chain are, thus, served as a set of activities undertaken by any firm to promote effective services in terms of integration. This refers to ' $[. .$.$] the degree to which an organization$ strategically collaborates with its supply chain partners and manages intra and inter-organization processes to achieve effective and efficient flows of products, services, information, money and decisions, with the objective of providing maximum value to its customers'.

\subsubsection{Supply Chain Integration}

Supply chain integration is a firm's strategic collaboration and coordination with its suppliers and customers and the management of internal and external organizational processes (Ellinger et al., 2012). The concept is best explained by development of strategic intra-firm and inter-firm collaboration along supply chain (Van der Vaart and Van Donk, 2008; Zhang and Huo, 2013). This has been widely regarded as an important strategy for improving firm performance (Flynn et al., 1990; 1994; Franklin, 2013). However, the implementation of integration within supply chain is not easy; it requires mutual adaptation and relation-specific investments among supply chain partners, which are often quite complicated and risky (Barney, 2012). As per Trierweiller et al., (2016), organizations achieving greater integration levels show the highest results, and the degree of perceived benefits systematically decreases according to the level of integration. Strategic management literature indicates that strategic network alliances, which are important aspects of supply chain have considerable failure rate (Chiang et al., 2010). Literature also suggests that full integration with suppliers and customers is rare; it stands far from ideal. To facilitate the implementation of integration within supply chain, it is necessary to identify the factors involved and monitor their effects on supply chain performance (Trkman et al., 2007).

\subsubsection{Firm Performance}

Cazeri et al. (2017) examined that supply chain performance measures have been orientated around cost, time and accuracy, conventionally. However, organizations are now coming under increased scrutiny from customers and governments regarding their compliance with environmental and social responsibility. Firm performance basically refers directly to how well any firm achieves its two polemic goals in its supply chain: market and financial goals (Chang et al., 2015). Academic studies measure firm performance within supply chain by using financial and market criteria (Ellinger et al., 2011). This includes adopting general items in the areas, such as return on investment, return on investment growth, market share, sales growth, profit margin on sales, etc. (Gunasekaran et al., 2004). Capabilities, such as lower prices, higher quality, greater variability, after sales service, etc. are deterrent factors to any firm to be in the better side of its competitors (Qrunfleh and Tarafder, 2014). Again, firm performance incorporating operations goals are rare in academic literature. Product design, product quality, delivery, capacity utilization, etc. are taken to measure firm performance in the line of operational issues (Bozarth et al., 2009). The present research reconciles all issues discussed above and aims to measure performance (taking into consideration the Indian business environment, including the product to service process). Some items, such as financial goals, may be feasible in marketing and operational area; valid for making constructs both in supply chain integration and information intensive services.

\section{RESEARCH FRAMEWORK WITH HYPOTHESIZED MODEL}

Indian firms, today, are facing intense competition globally; competition is not just between organizations, but among supply chains. Improving supply chain performance has become a continuous process that requires the successful application of information systems in an integrated manner. However, understanding how information intensive services affects firm performance directly as well as indirectly; or which areas are especially important; or whether there are any moderating effects that lead to firm performance, etc. is still not clear (Cliff, 1983). During the last few decades, academic and business research shows a nascent stage in relation to Indian business firms. The Indian manufacturing and service industry, its relationships, for example, are very imprecise and conflicting. Considering all these conflicts, the obvious question to be answered will be: How information intensive services can be effectively utilized in any supply chain? Researchers are, therefore, engaged in finding the link between information intensive services within supply chain that allows managers to actively perform better in real time. All these issues lead to framing the first hypothesis: 
$H_{1}$ : Firms with high level of Information Intensive Services will have a direct and positive effect of Firm performance.

Again, Information systems properly implemented with the key areas in a supply chain, industries can easily configure internal and external supply chain; communicate more effectively internally across functions and externally with suppliers and distributors (Grefen, 2013). Business firms first build up their supply chain framework, evaluate processes as adopted and compare their performance within and outside their industry segment, use benchmark and best practice data to prioritize their activities, quantify the potential benefits of specific process improvements, and determine financial justifications. Any firm that is pursuing the effective construction of information intensive service practices needs to pay attention to integration within a supply chain. However, the effective linkage between Information intensive services and integration with Supply chain practices, as seen in the extensive literature survey, is not easily accomplished. New information and communication technology that allows managers to actively integrate supply chain towards performance is still in its infancy (He et al., 2016). To explore all the above issues, the second hypothesis is framed as:

$\mathrm{H}_{2}$ : The firms with high levels of Information Intensive Services will have high levels of Supply chain integration.

Advancement in the information system within the domain of manufacturing strategy, the need for integration into the supply chain for firm's competence has been brought to light in studies of world-class manufacturers. Most problems the companies face are rooted in the lack of effective internal and external supply-chain integration (Li et al., 2002; Kim, 2009). By developing a high level of integration, firms are able to identify and eliminate non-value-added activities and subsequently can strengthen product quality and delivery reliability capabilities, thereby laying the foundations for better performance (Rosenzweig et al., 2003). Active research as led by Kim (2009) and Leuschner et al. (2013) found that supply-chain integration synchronizes core competencies and capabilities of all supply-chain participants in order to jointly achieve improved service capabilities at a lower cost. Again, there are a lot of extra advantages to firms that implement integrated supply chain practices and processes. The companies now realize that non-integrated sourcing, manufacturing or distribution processes and/ or poor relationships with suppliers and customers are inadequate for their success (Meixell and Luoma, 2015). Researchers claim that an integrated supply chain is necessary (not an option) and is a fundamental incentive for any firm's better performance. These characteristics, on one hand, and the significant importance of integration, on the other, urge practitioners to find an answer to the obvious questions:
How - and with whom - can supply chain be integrated in order to achieve better performance? To answer the above issues, the third hypothesis is framed accordingly:

$\mathrm{H}_{3}$ : The higher the level of Supply Chain Integration, the higher the level of Firm performance. The three hypotheses above, taken together, support the proposed framework as hypotheses and they are framed as shown in fig. 1 (in Appendix A).

The field based empirical study is a relatively new and promising area of operations management research (Kerlinger, 1986; Malhotra and Grover, 1998). Flynn et al. (1990) provided an excellent overview of the general survey methodology that should be followed in conducting empirical research in the real field. Fig. 1 presents Information Intensive Services (IIS) framework developed in this research. The IIS in this article is conceptualized as a multi-dimensional construct of framework that proposes that IIS will have an impact on Firm Performance (FP) both directly and also indirectly through the Supply Chain Integration (SCI). Supply Chain Integration and Firm Performance are concepts that have been operationalized. Using extensive literature support as discussed in the previous section, the inter relationship in between IIS, SCl and FP are developed and hypotheses are proposed (Cao and Zhang, 2011; Essex et al., 2016).

Reviewing and consolidating literature, three distinctive dimensions are identified to be measured for IIS: IIS for Resource Planning, IIS for Communication, and IIS for Tracking. These three constructs almost cover upstream and downstream areas of supply chain. Other factors may exist, but are not included due to the length and complexity of survey. The dimensions of the $\mathrm{SCl}$ constructs are taken as $\mathrm{SCl}$ for Sourcing, $\mathrm{SCl}$ for Partnership and $\mathrm{SCl}$ for Cross functional; while the dimensions of FP constructs are FP for Marketing, FP for Finances, and FP for Operations. The unit in this study is firm, as the IIS practices and responsiveness depend on the individual operating companies within the supply chain. The proposed framework is finally depicted in Fig.1 in Appendix A.

\section{RESEARCH METHODOLOGY}

Two major types of survey research are found in literature - 'exploratory' and 'explanatory' (Kerlinger, 1986). Exploratory research is very effective for the 'early stage' of research, whereas, as research matures, variables can be effectively measured and 'cause-effect relationship' can be established and measured effectively by the explanatory nature of research. Present research is explanatory and cross-sectional; using primary data sets through surveys as a part of the execution. 
Brazilian Journal of Operations \& Production Management

Volume 16, Número 2, 2019, pp. 241-260

DOI: 10.14488/BJOPM.2019.v16.n2.a7

\section{Item Generation / Pre Pilot Study / Pilot Study}

Instrument development methods for IIS practices include four stages: Item generation, Pre-pilot study, Pilot study, and Large-scale Data Analysis (Li, 2005). In the first stage of Item generation, items for IIS practice were generated basically on literature review and construct definitions, along with discussion and interviews with supply chain experts and practitioners working under the IS system (Soni and Kodali, 2016).

The pre-pilot study aims to pinpoint the problem area, reduce measurement error and respondent burden; determine whether or not respondents are interpreting questions correctly and accurately; and, finally, ensure that the order of questions does not influence the way respondents answer (Trafimow and MacDonald, 2017). Through the use of a pre pilot survey, researchers are able to ensure that questions are clearly articulated and that the response options are relevant, comprehensive, and mutually exclusive, and not just in their own estimation, but from the point of view of the respondents as well. Making sure that researchers and respondents interpret the survey in the same way is of the very significant concern in terms of survey design, and pre the pilot is one of the best ways to do this by assessing response latency (Converse and Presser, 1986).

In the pre-pilot study, the items generated are first reviewed by an interdisciplinary team of expert academicians and experienced senior managers. In this study, the items were evaluated through structured interviews with these practitioners who were asked to comment on the appropriateness of research constructs. The main focus was to check the relevance of each construct and clarity of the items set in a sample questionnaire. Based on feedback, redundant items were eliminated and new items were added according to the need and relevant demand wherever it was necessary. According to recommendations, some questions are re-worded to improve both domain of constructs and content validity. Specific changes were suggested in the second stage of pre-testing, and the interdisciplinary team of academicians and practicing managers were satisfied because the survey instrument was reasonably good to represent the framework for further research.

In Pilot study, Q-sort method was used to pre assesses the convergent and discriminant validity of scales (Watts and Stenner, 2005). The Q methodology, based on the correlation of people's view, not on the variables, has a significant importance for qualitative research (Shinebourne and Adams, 2007). The main background of factorizing individuals and not variables, hence the entire methodology is the concept of shared opinion. The $Q$ methodology is signally synthetic as it does not break the whole into parts, but keeps the parts up and evaluates the structure it is part of, a very important issue in terms of qualitative research in the domain of qualitative research (Josephine et al., 2007).

The vast majority of survey participants were business users of technology and they seem to generalize as IS support. Purchasing, materials, and supply chain managers working in the domain were requested to act as judges and sort the items into different dimensions of constructs, based on similarities and differences among items. An indicator of construct validity was the convergence and divergence of items within the categories. If an item was consistently placed within a particular category, then it was considered to demonstrate convergent validity with the related construct, and discriminant validity with others. The reliability of sorting conducted by the judges was assessed by using any of or all the three different measures: inter-judge raw agreement scores, Cohen's Kappa, and Item placement ratios (Hit Ratio's). Kappa value is checked to eliminate any chance agreements, thereby evaluating true agreement score between two judges. In the first round, Cohen's Kappa score was averaged 0.74 ; it is considered a good degree of agreement beyond chance, and between the judges. To further improve, an examination of the off-diagonal entries in placement matrix was conducted. Reworded items were then entered into the second round. The value of Cohen's Kappa agreement measure increased to 0.96; thereby indicated an excellent level of agreement for the judges in this round. The third round of sorting was planned to re-validate constructs already established. These results were similar to the second round of sorting, thereby indicating result consistency between the second and the third. Results finally suggested an excellent level of measure of agreement, indicating a high level of reliability and construct validity at this pilot testing stage (Watts and Stenner, 2005; Josephine et al., 2007).

\section{Large-Scale Data Analysis}

In large scale data analysis, the modified questionnaire was sent to respondents. Target number of samples/respondent was approximately 250 . For selecting any firm, a stratified random sampling scheme is used. Firm selection was also restricted according to their annual sales and number of employees. Stratification was made keeping geographical proximity of Indian business firms selected as east, west, north and south.

In next stage, from each stratified area, company selection is randomly done by covering prime process sectors to product manufacturing to consumer product to service sectors on the basis of annual sales and manpower, as participants in the survey. The respondents of this study are mostly top and middle level business managers working in different domains in supply chain and using information services intensively in their respective firms. The Likert Scaling 
technique has been used, as it is a measurement scale with five response categories ranging from 'strongly disagree' to 'strongly agree', which requires respondents to indicate a degree of agreement or disagreement with each of a series of statements related to stimulus objects. The Questionnaire that was finally developed was sent to 650 business managers (target population) through different modes of collecting data via mailing, meeting personal level, etc.

Collecting real life information from the business managers of Indian firms is extremely difficult; some firms under Aerospace, Defense, and Healthcare, among others, are reluctant to share information. In the first phase, the response rate was much lower. After repeated mails and meeting respondents personally, the response rate increased. Finally, out of the total number of questionnaires sent, a total of 233 completed questionnaires were received. All filled in questionnaire were checked to assess their suitability for further analysis. After extensive checking, 212 respondents were finalized as fit to move for statistical analyses. During the data collection period of more than 7 months in 2018, respondents' view were collected in many other ways, and did not find any significant difference of results, where respondents could differ in meaningful ways from non-respondents. With a reasonably good percentage of response, the absence of non-response bias is, thus, established and inferred accordingly.

Statistical analysis was used to determine the validity and reliability of IIS practices in terms of SCI and FP. In this study, the developed research hypothesis was tested by using Structural Equation Modeling. SEM is a methodology for representing, estimating and testing a network of relationships between variables; a multivariate technique that accounts measurement errors and is a very promising area of research that 'investigates the relationship between latent and measurement variables'. SEM examines the structure of these inter-relationships, expressed in a series of structural equations. In this research, constructs are unobservable or latent factors are represented by multiple variables. The latest research shows that SEM not only assess measurement properties and test proposed theoretical relationships by using a single technique, but also determines how well a proposed theory can explain the observed correlation or covariance matrix between measured variables (Brown and Maydeu-Olivares, 2018).

The SEM model consists of two models: measurement model and structural model. The measurement model depicts how observed (measured) variables represent construct. On the other hand, the structural model shows how constructs are interrelated to each other, often with multiple dependence relationships. In this case, SEM determines the contribution of each dimension in representing IIS, and evaluates how well a set of observed variables measuring these dimensions represent IIS. This information is incorporated into the estimation of relationships between IIS and other constructs. IIS has a direct and positive influence on both $\mathrm{SCl}$ and FP. These two, in turn, determine the intention to patronize IIS. Thus, both IIS and SCl act as a dependent and independent variables. A hypothesized dependent variable (IIS/SCI) can become an independent variable in a subsequent dependence relationship (explaining patronage intention). Since SEM is used to test causality, internal validity can be done informally through a discussion in terms of why causality exists or why alternate explanations are unlikely. One of the significant benefits of using this method is to test concurrent relationships among multiple variables; confidence in internal validity of the proposed model is enhanced.

\section{RESULT ANALYSIS}

The model, as proposed, is analyzed by Structural Equation Modeling. SEM is very helpful to disclose more concretely the role of $\mathrm{SCl}$ as a strategic 'lever', where a firm's supply chain practice and competitive capability can link efficiently and effectively with a firm's performance within the IIS domain. To examine unidimensionality, convergence and discriminant validity of measurement items, confirmatory factor analysis were conducted by using STATISTICA software. SEM cannot take direct data for software application, since the input is made in the Matrix form. However, depending on the complexity of the problem, the correlation matrix is checked for association between variables (Ferrando and Lorenzo-Seva, 2018).

In the proposed model, each latent variable (IIS, SCI, and FP) consists of a number of constructs. Each construct consists of a set of measurement or survey items. In this paper, IIS and $\mathrm{SCl}$ are considered latent-independent (exogenous) variables while FP is used as latent-dependent (endogenous) variables. IIS could be depicted as a latent construct that is not directly observed or measured; rather, it is represented by the three dimensions that are observed or measured. To conceptualize the perception of IIS as a lead by business managers in the Indian perspective, an initial survey is conducted by using 17 items. Based on the practitioner's feedback and literature review, three factors are identified as key contributors to measure the latent exogenous variable IIS. Looking into factors loading matrices and using domain expertise, the latent structure to be measured is finally identified as Recourse Planning, Communication, and Tracking.

A Factor Analysis was then conducted by using 17 items. The result of factor loadings is presented in a tabular form (Table 1). From the table with factor loading, it can be seen that the significant items are well represented by three factors named as IIS for Resource Planning (IIS/RP), IIS for Communication (IIS/Com), and IIS for Tracking (IIS/Track). Finally, these three factors conceptualize our IIS framework (Factor 
loadings - unrotated - are displayed with Principal Component's extraction).

For Supply Chain Integration, construct was initially represented by three dimensions/levels: a company's integration with sourcing practices (including insourcing and outsourcing - in order to cover a broad area of strategic partnership of suppliers in line with the supply chain) in terms of Suppliers, Cross functional integration within the company, and Partnership with other players within supply chain. To measure these three dimensions in the integration levels, namely $\mathrm{SCl}$ for Sourcing Practices (SCl/SP), SCI for Cross Functional (SCl/CF), and SCl for Partnership (SCl/PL); a total of 12 items were used. Factor loadings (Unrotated) are displayed in Table 2 with the extraction of the Principal Component. The result shows fairly good loadings between all factors.

Multi-dimensional indices ranging from financial factors to non-financial factors were used to comprehensively capture firm performance (Vázquez et al., 2016). Three factors emerged from the company performance, as it was analyzed by the factor. After rigorous examination of the descriptions of items, three dimensions were named as Market Performance (FP/Mktg.), Operational Performance (FP/Op.) and Financial Performance (FP/Fin.). For market based performance, five distinctive business goals are identified: namely market share, market performance, market share growth, sales growth, and customer satisfaction rating. Operational performances were measured for each sample firm in terms of product design, product quality, product delivery, capacity utilization, and product cost. Product cost is measured in operational aspects instead of financial, as it is directly aligned with product design and product quality. The financial performance of each company sampled was measured in terms of return on investment, growth of return on investment, inventory turnover, and profit margin on sales. Factor loadings (unrotated) are displayed in Table 3 for IIS impact on Firm Performance (with the extraction of the Principal Component)

\section{Assessing Reliability}

The reliability value of IIS, SCl and Firm Performance were assessed with Cronbach's Alpha. Table 4 represent means, standard deviations, correlations, and reliability values for each constructs. The reliability values that are greater than .60 for all constructs are considered acceptable (Nunnally, 1978) due to the domain and complexity of the selection of firms.

\section{Validation of second-order constructs}

Most SEM can be expressed as a Path Diagram. In STATISTICA, this program uses the command language [PATH] that is quite similar to a path diagram (The Model Syntax is depicted in Table 7). The main assumption (Maydeu-Olivares, 2017a; 2017b) adopted in this research is: variables are interrelated. The program works through some complex internal rules, thus affecting the variances and co-variances of variables. The program tests whether the variances and covariances fit this model. The program reports the results of statistical testing and also returns parameter estimates and standard errors for numerical coefficient in linear equations.

\section{Model Validation}

The validity of the structural model is to examine fitness, comparing the proposed model, and testing the structural relationships and hypotheses. Model fitness is determined by comparing how closely the estimated covariance matrix matches the observed covariance matrix (sample) (Shi et al., 2017). In moving from measurement to the structural model, emphasis shifts from relationships between the latent constructs and observed variables to nature and magnitude of relationships between constructs. SEM models with five or fewer constructs, each with more than three measured variables, and communalities of at least 0.5 should be estimated with sample sizes of at least 200. The model estimates for interrelationship between IIS, SCI and FP are depicted in Table 5 , where the structural equation of IIS, which leads to FP within $\mathrm{SCl}$ platform, is established. The results of CFA indicate that the model fits the data well (Savalei, 2012). The basic summary statistics of Structural Equation with these interrelationships is shown in Table 6.

From this analysis, result may be signified and inferred in the following ways: Discrepancy function is basically a mathematical function that confers how closely a structural model conforms to the observed data. The larger values of this function indicate a 'poor fit' of the model to data (Marcoulides and Yuan, 2017). However, it is non-negative and, for a value of zero, it will be a perfect fit. The present study shows a very small value $(=0.0068)$, which is deemed significantly fit for the model to data (Barrett, 2007). The Maximum Residual Cosine and Maximum Absolute Gradient values are close to zero; this indicates a reasonably good fit of model to data (Zhang and Savalei, 2016). Other statistics, such as ICSF and ICS criterion values, seem to fit well the lower value. The probability level value of Chisquare statistic is also well within the range for a model to be a 'good fit' (Bentler, 1990). Finally, the RMS Standardized Residual value is 0.0018 ; it is less than 0.05 for the fit to be good in a practical sense (Brosseau-Liard et al., 2012; Kenny et al., 2015). Therefore, it can be finally inferred that the proposed hypothesized model fits well with the current set of data. 


\section{MANAGERIAL OUTPUT}

The managing supply chain, in the best optimal way, has now become a significant topic in modern business management. It explores a new innovative approach to manage business with sustained competitiveness. In this study, applying SEM can concurrently confirm the entire measurement structures for a number of variables by testing the level of 'fit'-ness with data (Savalei, 2012). The strength of this study may be highlighted under the era of Industry 4.0 in the following ways: the literature has been surveyed for over twenty years by analyzing both pre- and post- facto scenario of the Indian firm's investments in IT services, taking multiple respondents from each participating companies (Collecting information from a single respondent may generate measurement inaccuracy); Responses have been taken from the pairs of firms at the two ends of the supply chain in order to increase variability and randomness in collecting information; Information is collected from restricted, but diversified groups of peoples; and an Attempt has been made to cover all distinct types of firms in a stratified random manner. Finally, pertinent information, such as employee size, job title, and size of the companies' revenue has been taken care of while collecting information. Final the results of three hypotheses are as follows:

Final results for Structural Equation Modelling

\begin{tabular}{|c|c|c|c|}
\hline Hypothesis & Relationship & Direct effects & Remarks \\
\hline H1 & IIS to FP & $0.364(\mathrm{t}=2.010)$ & $\begin{array}{c}\text { Hypothesis } \\
\text { supported }\end{array}$ \\
\hline H2 & IIS to SCI & $0.611(\mathrm{t}=3.010)$ & $\begin{array}{c}\text { Hypothesis } \\
\text { supported }\end{array}$ \\
\hline H3 & SCl to FP & $0.463(\mathrm{t}=2.570)$ & $\begin{array}{c}\text { Hypothesis } \\
\text { supported }\end{array}$ \\
\hline
\end{tabular}

The results support Hypothesis 1, which states that the efficient use of IIS by firms yield a high level of Firm Performance. The standardized coefficient is 0.364 , which is statistically significant at $\mathrm{P}<0.05(\mathrm{t}=2.010)$. From the value itself, it can be said that, IIS practice have a moderate influence directly on Firm Performance. Strategically, it may have a better impact (direct influence) on the firms' marketing and operational performance.

Hypothesis 2, as proposed, also supports the direct impact of IIS on Supply Chain Integration. The standardized coefficients, as calculated, is 0.611 , which is statistically significant at $\mathrm{P}<0.05(\mathrm{t}=3.010)$. This value concludes that, IIS has more impact directly in framing the Supply Chain Integration than on Firm Performance.

Hypothesis 3, as proposed, is also significant with the value of 0.463 at $P<0.05(t=2.570)$. This indicates a positive impact in between Supply Chain Integration and Firm Performance. This fact supports the proposition of this study that a higher level of integration leads to a higher performance.

Based on the value of the three standardized coefficients above, as constructed by the three hypotheses, it can be highlighted the direction of the managerial output, as follows:

1. IIS is more directly impactant on the Supply Chain Integration (0.611) than on Firm Performance (0.364). This is true in the sense that Firm Performance usually depends on mixed effects of different qualitative and quantitative factors; thus, it may not segregate any one of the deterrent factors that will dominantly influence Performance (Qi et al., 2017).

2. Firm Performance is more vividly influenced by Supply Chain Integration (0.463) than by Information Integrative services (0.364). This is logical and true; especially in terms of Indian firms, in the sense that the good practices of IIS will yield more integration to the supply chain; it will subsequently lead to performance. This inference may not match most of the literature surveyed; however, the presence of the mediating effect of supply chain integration, in conjunction with IIS and Firm performance, is established in the Indian business scenario (Soni and Kodali, 2016).

\section{LIMITATIONS AND FUTURE DIRECTION OF RESEARCH}

The high quality survey-based research in the area of Operations Management is in a state of transition from the use of traditional modeling-based methodologies to the empirical field-based one (Malhotra and Grover, 1998). Data collection needs a long lead time, and analysis also lead to a time lag, whereby years pass between the actual conceptualization of a study and its publication. This should be kept in mind while interpreting the implication of the findings (Rungtusanatham et al., 2014). Another very important issue of critiques in terms of the application of the SEM is issue of 'causal interpretation'. Most SEM applications are aimed at non-experimental data; nevertheless, it interprets the final model as a causal model. Most significantly, SEM transforms correlation data into causal conclusion. The fact that the SEM model has corroborated data does not mean it has been proven true. Hypothesis, as framed by western standards, seems to be obvious; however, considering Indian business, where supply chain and technology integration are still in nascent stage, this seems to be a very significant area of research. 
Again, IIS practice will be definitely high and yield better results when the coordination within the supply chain works in an efficient way. With proper collaboration, firms were able to set procedures in their dealings with partners, sharing knowledge and processes and, subsequently, joint-planning and investing with them for better operations, systems and processes in the supply chain. However, in reality, Supply chain collaboration has proved difficult to implement. There should be an over-reliance on technology in trying to implement it. In the integration parlance, it may work even better (Durugbo and Riedel, 2013).

Future studies may be directed to examine the proposed relationship by incorporating other contextual factors, such as firm size, and supply chain structure and complexity, which is a company's position in the supply chain (Lu et al., 2018). It will be intriguing to examine how IIS differs across firm size within an integrated supply chain. Again, in this study, an attempt was made to establish the causal relationship in between IIS, SCI and $\mathrm{FP}$ and 'ignore possible recursive relationships'. It may also be possible that a better supply chain integration and increased firm performance could have improved levels of IIS practice; however, this is beyond the present scope of this research. Therefore, further study is envisaged in that direction.

\section{CONCLUSION}

Innovation management has received increasing attention in the field of operations management in recent years (Christopher and Ryals, 2014). Academics and business managers have long been discussing the innovation nature and its importance for the organization's growth and competitive advantage (Lopes et al., 2016); however, one issue that remains unclear is how to recognize what type of strategic transition is required for any firm (Gaiardelli et al., 2015).

To be sustainable in the pace of 'Innovation and Management of Technology in the Industry 4.0 era', as in the case of other firms operating globally, Indian firms must realize that real competition is not only firm to firm, but supply chain to supply chain. Although it started late, in comparison with global players, these companies realize and thus elevate the level of integration between technologies with supply chain practices. Issues underlying integration in supply chain are more appropriate, as any firm tries to improve real-time performance. Over time, the use of Information systems in supply chains has been thematic; Indian firms perceive the upgradation of the technological system. In this perspective, management should accept the idea that strategic alliance has become a potentially valuable ways of ensure effective supply chain practices and thus improve company performance. Results indicate that, without integration, higher levels of information intensive services cannot lead to im- proved firm performance, and supply chain integration has a direct and positive impact on firm performance. In the face of a changing and competitive world, continuous development becomes necessary, but it is not a sufficient condition for sustained leadership. Any firm with a superior information system capability, for example, is likely to lose its leadership status if it fails to upgrade its capability at a rate faster than its competitors in its supply chain's 'integrated and winto-sustain phenomena'.

Finally, Industry 4.0 ensures for every organization that, in order to build a harmony between innovation and technology within the supply chain, innovation concepts are not only an alternative to introducing new products or increasing their production capacity by changing their internal processes. Rather, it is a way to influence and change the industry to which they belong (Frow et al., 2015). The subject of innovation management in the Industry 4.0 era and its impact on operation management in the Indian business scenario are still in an evolutionary stage. A better understanding of the subject and its effect on internal processes and organizational strategy is needed; and the area is open for further research.

\section{REFERENCES}

Autry, C. W.; Rose, W. J.; Bell, J. E. (2014), “Reconsidering the supply chain integration performance relationship: in search of theoretical consistency and clarity", Journal of Business Logistics, Vol. 35, No. 3, pp. 275-276.

Barney, J. B. (2012), "Purchasing, supply chain management and sustained competitive advantage: the relevance of resource-based theory", Journal of Supply Chain Management, Vol. 48, No. 2, pp. 3-6.

Barrett, P. (2007), "Structural equation modelling: Adjudging model fit", Personality and Individual Differences, Vol. 42, pp. 815-824.

Bayraktar, E. (2009), "A causal analysis of the impact of information systems and supply chain management practices on operational performance: Evidence from manufacturing SME's in Turkey", International Journal of Production Economics, Vol. 122, pp. 133-149.

Bentler, P. M. (1990), “Comparative fit indexes in structural models", Psychological Bulletin, Vol. 107, pp. 238-246.

Bernon, M.; Upperton, J.; Bast, M.; Cullen, J. (2013), “An exploration of supply chain integration in the retail product returns process", International Journal of Physical Distribution \& Logistics Management, Vol. 43, No. 7, pp. 586-608.

Bozarth, C.; Warsing, D.; Flynn, B.; Flynn, E. (2009), "The impact of supply chain complexity on manufacturing plant performance", Journal of Operations Management, Vol. 27, No. 1, pp. 78-93. 
Brosseau-Liard, P. E.; Savalei, V.; Li, L. (2012), “An investigation of the sample performance of two non normality corrections for RMSEA", Multivariate Behavioral Research, Vol. 47, pp. 904-930.

Brown, A.; Maydeu-Olivares, A. (2018), “Ordinal Factor Analysis of Graded-Preference Questionnaire Data", Structural Equation Modelling: A Multidisciplinary Journal, Vol. 25, No. 4, pp. 516-529.

Cai, J.; Liu, X.; Xiao, Z.; Liu, J. (2009), “Improving supply chain performance management: a systematic approach to analyzing iterative KPI accomplishment", Decision Support Systems, Vol. 46, No. 2, pp. 512-521.

Cai, S.; Jun, M.; Yang, Z. (2010), “Implementing supply chain information integration in China: the role of institutional forces and trust", Journal of Operations Management, Vol. 28 , No. 3, pp. 257-268.

Cao, M.; Zhang, Q. (2011), "Supply Chain Collaboration: Impact on Collaborative Advantage and Firm Performance", Journal of Operations Management, Vol. 29, No. 3, pp. 163-180.

Cazeri, G.; Anholon, R.; Ordoñez, R. E.; Novaski, O. (2017), "Performance measurement of green supply chain management: a literature review and gaps for further research", Brazilian journal of operations \& production management, Vol. 14 , No. 1 , pp. $60-72$.

Chang, W.; Ellinger, A. E.; Kim, K. K.; Franke, G.R (2015), "Supply chain integration and firm financial performance: $A$ meta-analysis of positional advantage mediation and moderating factors", European Management Journal, Vol. 34, No. 3, pp. 282-295.

Chen, D.; Preston, D. S.; Xia, W. (2013), “Enhancing hospital supply chain performance: a relational view and empirical test", Journal of Operations Management, Vol. 31, No. 6, pp. 391-408.

Chiang, K.; Shiuh-Nan, H. (2010), "Efficiency measurement for network systems: IT impact on firm performance", Decision Support System, Vol. 48, No. 3, pp. 437-446.

Christopher, M.; Holweg, M. (2011), "Supply chain: managing supply chains in the era of turbulence", International Journal of Physical Distribution \& Logistics Management, Vol. 41, No. 1, pp. 63-82.

Christopher, M.; Ryals, J. L. (2014), "The Supply Chain Becomes the Demand Chain", Journal of Business Logistics, 35, No. 1, pp.29-35.

Cliff, N. (1983), "Some cautions concerning the application of causal modeling methods", Multivariate Behavioral Research, Vol. 18, pp. 115-126.

Converse, J. M.; Presser, S. (1986), "Survey Questions. Handcrafting the Standardized Questionnaire", Quantitative Applications in the Social Sciences Series, No. 63, Sage, Beverly Hills. USA.
Craig, R.; Carter, D.; Rogers, S.; Thomas Y. Choi (2015), "Toward the Theory of the Supply Chain", Journal of Supply Chain Management, Vol. 51, No. 2, pp. 89-97.

DeGroote, S.; Marx, T.G. (2013), "The impact of IT on supply chain agility and firm performance: an empirical investigation", International Journal of Information Management, Vol. 33, No. 6, pp. 909-916.

Durugbo, C.; Riedel, J. C. K. H. (2013), “Readiness Assessment of Collaborative Networked Organisations for Integrated Product and Service Delivery", International Journal of Production Research, Vol. 51, No. 2, pp. 598-613.

Ellinger, A. E.; Natarajarathinam, M.; Adams, F. G.; Gray, J. B.; Hofman, D.; O’Marah, K. (2011), "Supply chain management competency and firm financial success", Journal of Business Logistics, Vol. 32, No. 3, pp. 214-226.

Ellinger, A. E.; Shin, H.; Northington, W. M.; Adams, F. G.; Hofman, D.; O'Marah, K. (2012), "The influence of supply chain management competency on customer satisfaction and shareholder value", Supply Chain Management: An International Journal, Vol. 17, No. 3, pp. 249-262

Ellram, L. M.; Cooper, M. C. (2014), "Supply chain management: It's all about the journey, not the destination", Journal of Supply Chain Management, Vol. 50, No.1, pp. 8-20.

Eskandarpour, M. et al. (2015), "Sustainable supply chain network design: An optimization-oriented review", Omega, Vol. 54, pp. 11-32.

Essex, A.; Subramanian, N.; Gunasekaran, A. (2016), "The Relationship Between Supply Chain Manager Capabilities and Performance: Empirical Evidence", Production Planning \& Control, Vol. 27, No. 3, pp. 198-211.

Ferrando, P. J.; Lorenzo-Seva, U. (2018), “Assessing the Quality and Appropriateness of Factor Solutions and Factor Score Estimates in Exploratory Item Factor Analysis", Educational and Psychological Measurement, Vol. 78, No. 5, pp. pages $762-780$.

Flynn, B. B.; Huo, B.; Zhao, X. (2010), "The impact of supply chain integration on performance: a contingency and configuration approach", Journal of Operations Management, Vol. 28, No. 1, pp. 58-71.

Flynn, B. B.; Sakakibara, S.; Schroeder, R. G. (1994), “A framework for quality management research and an associated measurement instruments", Journal of Operations Management, Vol. 11, No. 4, pp. 339-366.

Flynn, B. B.; Sakakibara, S.; Schroeder, R. G.; Bates, K. A.; Flynn, E. J. (1990), "Empirical research methods in operations management", Journal of Operations Management, Vol. 9, No. 2, pp. 250-284.

Franklin, C. L. (2013), "Developing expertise in management decision-making", Academy of Strategic Management Journal, Vol. 12, No.1, pp. 21-37. 
Brazilian Journal of Operations \& Production Management

Volume 16, Número 2, 2019, pp. 241-260

DOI: 10.14488/BJOPM.2019.v16.n2.a7
Frohlich, M. T. (2002), "E-integration in the supply chain: Barriers and performance", Decision Sciences, Vol. 33, No. 4, pp. 537-556.

Frow, P.; Nenonen, S.; Payne, A.; Storbacka, K. (2015), “Managing Co-creation Design: A Strategic Approach to Innovation", British Journal of Management, Vol. 26, No. 3, pp. 463-483.

Gaiardelli, P.; Martinez, V.; Cavalieri, S. (2015), “The Strategic Transition to Services: A Dominant Logic Perspective and Its Implications for Operations." Production Planning \& Control, Vol. 26, No. 14/15, pp. 1165-1170.

Grefen, P. (2013), “Networked Business Process Management", International Journal of IT/Business Alignment and Governance, Vol. 4, No. 2, pp. 54-82.

Gunasekaran, A. P. C.; McGaughey, E. (2004), “A framework for supply chain performance measurement", International Journal of Production Economics, Vol. 87, pp. 333-347.

Gunasekaran, A.; Ngai, E. (2004), "Information Systems in Supply Chain Integration and Management", European Journal of Operational Research, Vol. 159, No. 2, pp. 269-295.

He, T.; Ho, W.; Zhang, Y.; Dey, P. K. (2016), “Organizing the Business Processes of a Product Servitized Supply Chain: A Value Perspective", Production Planning \& Control, Vol. 27, No. 5, pp.378-393.

Hitt, M. A. (2011), "Relevance of strategic management theory and research for supply chain management", Journal of Supply Chain Management, Vol. 47, No. 1, pp. 9-13.

Houlihan, J. B. (1985), "International Supply Chain Management", International Journal of Physical Distribution and Materials Management, Vol. 15, No. 1, pp. 22-38.

Houlihan, J. B. (1987), "International Supply Chain Management", International Journal of Physical Distribution and Materials Management, Vol. 17, No. 2, pp. 51-66.

Huo, B.; Zhaojun, H.; Xiande Z.; Honggeng, Z.; Craig, H.; Xin, Z. (2013), "The impact of Institutional pressures on supplier integration and financial performance: Evidence from China", International Journal of Production Economics, Vol. 146, No. 1, pp. 82-94.

Jin, Y. H.; Fawcett, A. M.; Fawcett, S. E. (2013), "Awareness is not enough: commitment and performance implications of supply chain integration", International Journal of Physical Distribution and Logistics Management, Vol. 43, No. 3, pp. 205-230.

Josephine, P.; Barbara, P.; Fiona, H. (2007), “Q Methodology and Rural Research", Sociologia Rurals - Journal of the European Society for Rural Sociology, Vol. 47, No. 2, pp. 135-147.

Kaufmann, L.; Meschnig, G.; Reimann, F. (2014), “Rational and intuitive decision-making in sourcing teams: effects on decision outcomes", Journal of Purchasing and Supply Management, Vol. 20, No. 2, pp. 104-112.
Keller, F.; Daronco, E.; Cortimiglia, M. (2017), "Strategic tools and business modeling in an information technology firm", Brazilian Journal of Operations \& Production Management, Vol. 14, No. 3, pp. 304-317.

Kenny, D. A.; Kaniskan, B.; McCoach, D. B. (2015), "The performance of RMSEA in models with small degrees of freedom", Sociological Methods \& Research, Vol. 44, pp. 486-507.

Kerlinger, F. N. (1986), "Foundations of behavioral research", Holt. Rinchart \& Winston, New York: USA

Kim, S. W. (2009), "An Investigation on the Direct and Indirect Effect of Supply chain Integration on Firm Performance", International Journal of Production Economics, Vol. 119, No. 2, pp. 328-346.

Leuschner, R.; Rogers, D. S.; Charvet, F. F. (2013), “A meta-analysis of supply chain integration and firm performance", Journal of Supply Chain Management, Vol. 49, No. 2, pp. 3457.

Li, S. (2005), "Development and validation of a measurement instrument for studying supply chain management practices", Journal of Operations Management, Vol. 23, No. 6, pp. 618-641.

Li, S.; Ragu-Nathan, B.; Ragu-Nathan, T. S.; Rao, S. S. (2006), "The impact of supply chain management practices on competitive advantage and organizational performance", Omega, Vol.34, No. 2, pp.107-124.

Li, S.; Rao, S.; Ragu-Nathan, T. S.; Ragu-Nathan, B. (2002), "An Empirical Investigation of Supply Chain Management Practices", Proceedings of the 33rd annual meeting of the Decision science institute, San Diego, CA, USA: Nov. 23-26, 2002.

Lopes, A. P.; Kissimoto, K.; Salerno, M.; Carvalho, M.; Laurindo, F. (2016), "Innovation management: a systematic literature analysis of the innovation management evolution", Brazilian Journal of Operations \& Production Management, Vol.13, No.1, pp. 16-30.

Lu, G. et al. (2018), “Addressing endogeneity in operations management research: Recent developments, common problems, and directions for future research", Journal of Operations Management, Vol. 64, No. 1, pp. 53-64.

Malhotra, M. K.; Grover, V. (1998), “An assessment of survey research in POM: from construct to theory", Journal of Operations Management, Vol. 16, No. 4, pp. 407-425.

Marcoulides, K. M.; Yuan, K. H. (2017), “New Ways to Evaluate Goodness of Fit: A Note on Using Equivalence Testing to Assess Structural Equation Models", Structural Equation Modelling: A Multidisciplinary Journal, Vol. 24, No. 1, pp. 148153.

Maydeu-Olivares, A. (2017a), "Assessing the size of model misfit in structural equation models", Psychometrika, Vol. 82, pp. 533-558. 
Maydeu-Olivares, A. (2017b), "Maximum likelihood estimation of structural equation models for continuous data: Standard errors and goodness of fit", Structural Equation Modeling, Vol. 24, pp. 383-394.

Meixell, M. J.; Luoma, P. (2015), "Stakeholder pressure in sustainable supply chain management: a systematic review", International Journal of Physical Distribution \& Logistics Management, Vol. 45, Nos 1/2, pp. 69-89.

Mentzer, J. T.; Min, S.; Zacharia, Z. G. (2000), "The nature of inter-firm partnership in supply chain management", Journal of Retailing, Vol. 76, No. 4, pp. 549-68.

Narasimhan, R.; Swink, M.; Viswanathan, S. (2010), “On decisions for integration implementation: An examination of complementarities between product- process technology integration and supply chain integration", Decision Sciences, Vol. 41, No. 2, pp. 355-372.

Nunnally, J. C. (1978), "Psychometric Theory", New York, NY, USA: McGraw-Hill.

Podsakoff, P. M.; MacKenzie, S. B.; Podsakoff, N. P. (2012), "Sources of method bias in social science research and recommendations on how to control it", Annual Review of Psychology, Vol. 63, No. 1, pp. 539-569.

Prajogo, D.; Olhager, J. (2012). Supply chain integration and performance: the effects of long- term relationships, information technology and sharing, and logistics integration. International Journal of Production Economics, Vol. 135, No. 1, pp. 514-522.

Qi, Y.; Huo, B.; Wang, Z.; Yeung, H. Y. J. (2017), “The Impact of Operations and Supply Chain Strategies on Integration and Performance", International Journal of Production Economics, Vol. 185, pp. 162-174.

Qrunfleh, S.; Tarafdar, M. (2014), "Supply Chain Information Systems Strategy: Impacts on Supply Chain Performance and Firm Performance", International Journal of Production Economics, Vol. 147, pp. 340-350.

Rosenzweig, E. D.; Roth, A. V.; Dean Jr., J. W. (2003), “The influence of an integration strategy on competitive capabilities and business performance: an exploratory study of consumer products manufactures", Journal of Operations Management, Vol. 21, pp. 437-456.

Rungtusanatham, M.; Miller, J. W.; Boyer, K. K. (2014), "Theorizing, testing, and concluding for mediation in SCM research: tutorial and procedural recommendations", Journal of Operations Management, Vol. 32, No. 3, pp. 99-113.

Savalei, V. (2012), "The relationship between root mean square error of approximation and model misspecification in confirmatory factor analysis models", Educational and Psychological Measurement, Vol. 72, pp. 910-932.

Shi, D.; Lee, T.; Terry, R. A. (2017), "Revisiting the model size effect in structural equation modelling", Structural Equation Modelling, Vol. 50, pp.1-20.
Shinebourne, P.; Adams, M. (2007),"Therapists' understandings and experiences of working with clients with problems of addiction: a pilot study using Q methodology", Counselling and Psychotherapy Research, Vol. 7, No. 4, pp. 211-219.

Soni, G.; Kodali, R. (2016), "Path Analysis for Proposed Framework of SCM Excellence in Indian Manufacturing Industry", Journal of Manufacturing Technology Management, Vol. 27, No. 4, pp. 577-611.

Soosay, C. A.; Hyland, P. (2015), "A decade of supply chain collaboration and directions for future research", Supply Chain Management: An International Journal, Vol. 20, No. 6, pp. 613-630.

Stock, G. N.; Tatikonda, M. V. (2008), “The joint influence of technology uncertainty and inter-organizational interaction on external technology integration success", Journal of Operations Management, Vol. 26 No. 1, pp. 65-80.

Stoel, M. D.; Muhanna, W. A. (2009), "IT capabilities and firm performance: A contingency analysis of the role of industry and IT capability type", Information and Management, Vol. 46, No. 3, pp. 181-189.

Su, Y. F.; Yang, C. (2010), "A structural equation model for analyzing the impact of ERP on SCM", Expert Systems with Applications, Vol. 37, No. 1, pp. 456-469.

Szozda, N. (2017), "Industry 4.0 and its impact on the functioning of supply chains", Logforum 2017, 13-27.

Trafimow, D.; MacDonald, J. A. (2017), "Performing Inferential Statistics Prior to Data Collection", Educational and Psychological Measurement, Vol. 77, No. 2, pp. 204-219.

Trierweiller, A. (2016), "An exploratory survey on the topic integrated management systems", Brazilian journal of operations \& production management, Vol. 13, No. 2, pp.184-193.

Trkman, P.; Stemberger, M. I.; Jaklic, J.; Groznik, A. (2007), "Process Approach to Supply Chain Integration", Supply Chain Management: an International Journal, Vol. 12, No. 2, pp. 116-128.

Van der Vaart, T.; Van Donk, D. P. (2008), “A critical review of survey-based research in supply chain integration", Journal of Production Economics, Vol. 111, No. 31, pp. 42-55.

Vázquez, X. H.; Sartal, A.; Lozano-Lozano, L. M. (2016), "Watch the Working Capital of Tier-Two Suppliers: A Financial Perspective of Supply Chain Collaboration in the Automotive Industry", Supply Chain Management: An International Journal, Vol. 21, No. 3, pp. 321-333.

Watts, S.; Stenner, P. (2005), "Doing Q methodology: Theory, method and interpretation", Qualitative Research in Psychology, Vol. 2, pp. 67-91.

Williams, B. D.; Roh, J.; Tokar, T.; Swink, M. (2013), “Leveraging supply chain visibility for responsiveness: the moderating 
D Brazilian Journal of Operations \& Production Management Volume 16, Número 2, 2019, pp. 241-260

DOI: 10.14488/BJOPM.2019.v16.n2.a7

role of internal integration", Journal of Operations Management, Vol. 31 No. 7, pp. 543-554

Williamson, O. E. (2008), "Outsourcing, transaction cost economics and supply chain management", Journal of Supply Chain Management, Vol. 44, No. 2, pp. 5-16.

Winter, M.; Knemeyer, A. M. (2013), “Exploring the integration of sustainability and supply chain management: current state and opportunities for future inquiry", International Journal of Physical Distribution \& Logistics Management, Vol. 43, No. 1, pp. 18-38.

Wu, S. J.; Melnyk, S. A.; Flynn, B. B. (2010), “Operational capabilities: the secret ingredient", Decision Science, Vol. 4, No. 4, pp. 721-754.

Xia, Y.; Zu, X.; Shi, C. (2015), "A profit-driven approach to building a 'people-responsible' supply chain", European Journal of Operations Research, Vol. 241, No. 2, pp. 348-260.
Yang, J. (2014), "Supply chain agility: securing performance for Chinese manufacturers", International Journal of Production Economics, Vol. 150, pp. 104-113.

Zhang, M.; Huo, B. (2013), "The impact of dependence and trust on supply chain integration", International Journal of Physical Distribution and Logistics Management, Vol. 43, No. 7, pp. 544-563.

Zhang, X.; Savalei, V. (2016), "Bootstrapping confidence intervals for fit indexes in structural equation modeling", Structural Equation Modeling, Vol. 23, pp. 392-408.

Zimmermann, F.; Forest, K. (2014), "A meta-analysis of the purchasing and supply management practice-performance link", Journal of Supply Chain Management Vol. 50, No. 3, pp. 37-54.

Acknowledgement: The authors sincerely acknowledged anonymous Reviewers' most valuable report to make this paper more academically sound and improve the shape in the form of revised version.

\section{Appendix-A}

PROPOSED FRAMEWORK

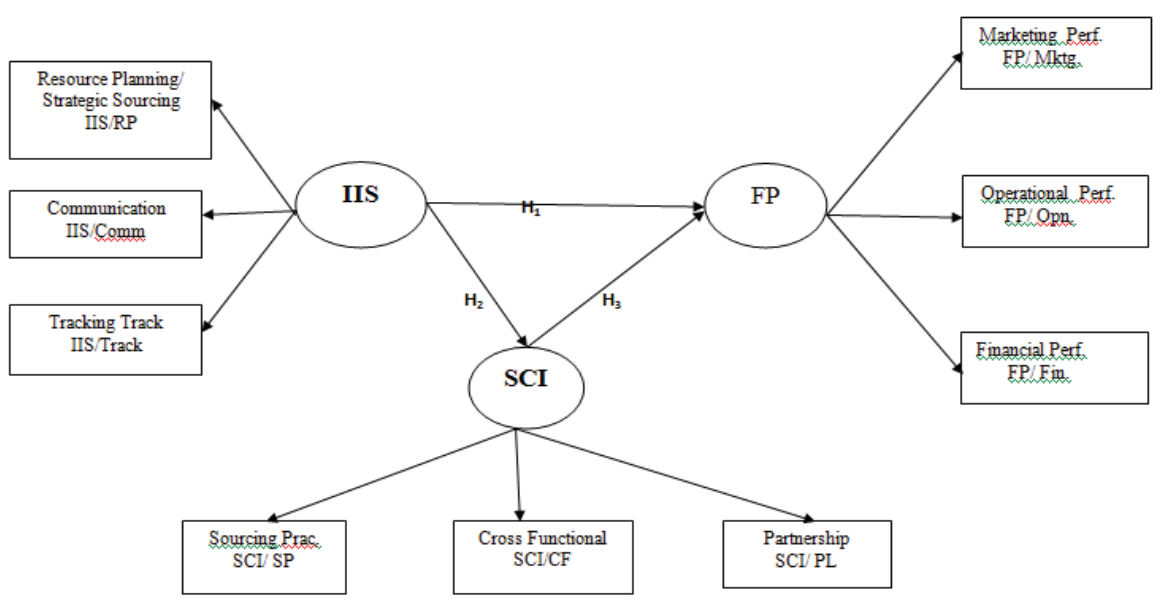

Figure 1. Proposed Framework 
Table 1. Factor Loadings (Unrotated) - Data for IS impact

\begin{tabular}{|c|c|c|c|c|}
\hline \multirow[b]{2}{*}{ Variable } & \multicolumn{4}{|c|}{$\begin{array}{l}\text { Factor Loadings (Unrotated) (data for IS impact.IIS) } \\
\text { Extraction: Principal components } \\
\text { (Marked loadings are }>-600000)\end{array}$} \\
\hline & Factor 1 & Factor 2 & Factor 3 & \\
\hline V1 & 0.830143 & 0.041748 & 0.089595 & \\
\hline$\sqrt{2}$ & 0.595598 & 0.081862 & 0.098034 & \\
\hline$\sqrt{3}$ & 0.669663 & 0.161739 & 0.048484 & \\
\hline V4 & 0.337399 & 0.347021 & 0.212314 & \\
\hline V5 & 0.492388 & 0.074502 & 0.349205 & \\
\hline V6 & 0.607783 & 0.210121 & 0.090252 & \\
\hline$\sqrt{7}$ & 0.089224 & 0.726552 & 0.022812 & \\
\hline V8 & 0.072636 & 0.648550 & 0.143637 & \\
\hline V9 & 0.083926 & 0.846425 & 0.045940 & \\
\hline V10 & 0.087483 & 0.765537 & 0.024033 & \\
\hline V11 & 0.026473 & 0.678233 & 0.112511 & \\
\hline V12 & 0.052979 & 0.236319 & 0.155195 & \\
\hline V13 & 0.096742 & 0.083382 & 0.836391 & \\
\hline V14 & 0.095080 & 0.026305 & 0.898097 & \\
\hline V15 & 0.084673 & 0.070652 & 0.820857 & \\
\hline V16 & 0.093331 & 0.043403 & 0.601509 & \\
\hline V17 & 0.091361 & 0.067235 & 0.716139 & \\
\hline
\end{tabular}

Table 2. Factor Loading- Data for IS impact on SCl

\begin{tabular}{|c|c|c|c|c|}
\hline \multirow[b]{2}{*}{ Variable } & \multicolumn{4}{|c|}{$\begin{array}{l}\text { Factor Loadings (Unrotated) (data for IS impact on SCI) } \\
\text { Extraction: Principal components } \\
\text { (Marked loadings are }>.600000)\end{array}$} \\
\hline & Factor 1 & Factor 2 & Factor 3 & \\
\hline V1 & 0.821508 & 0.013477 & 0.091522 & \\
\hline V2 & 0.530704 & 0.047469 & 0.079068 & \\
\hline V3 & 0.070920 & 0.620548 & 0.033441 & \\
\hline V4 & 0.364641 & 0.731595 & 0.202376 & \\
\hline V5 & 0.096658 & 0.692502 & 0.345528 & \\
\hline V6 & 0.115114 & 0.596700 & 0.179077 & \\
\hline V7 & 0.089885 & 0.624376 & 0.118525 & \\
\hline V8 & 0.073048 & 0.174614 & 0.673705 & \\
\hline V9 & 0.184449 & 0.214440 & 0.633297 & \\
\hline V10 & 0.085246 & 0.090387 & 0.547022 & \\
\hline V11 & 0.128141 & 0.174312 & 0.811653 & \\
\hline V12 & 0.175904 & 0.120536 & 0.596893 & \\
\hline
\end{tabular}


Table 3. Factor Loading - Data for IS impact on Firm Performance

\begin{tabular}{|c|c|c|c|c|}
\hline \multirow[b]{2}{*}{ Variable } & \multicolumn{4}{|c|}{$\begin{array}{l}\text { Factor Loadings (Unrotated) (data for IS impact on FP) } \\
\text { Extraction: Principal components } \\
\text { (Marked loadings are }>.600000 \text { ) }\end{array}$} \\
\hline & Factor 1 & Factor 2 & Factor 3 & \\
\hline V1 & 0.573400 & 0.495391 & 0.062952 & \\
\hline V2 & 0.551246 & -0.193320 & 0.186488 & \\
\hline V3 & 0.618031 & 0.070343 & 0.185117 & \\
\hline V4 & 0.684131 & -0.029512 & 0.154395 & \\
\hline V5 & 0.638853 & -0.297798 & 0.052372 & \\
\hline V6 & 0.045670 & 0.714079 & 0.012704 & \\
\hline V7 & 0.065795 & 0.825289 & 0.027102 & \\
\hline V8 & 0.170363 & 0.767940 & 0.051712 & \\
\hline V9 & 0.195321 & 0.619603 & 0.046984 & \\
\hline V10 & 0.060179 & 0.877996 & 0.030320 & \\
\hline V11 & 0.286774 & 0.048514 & 0.645001 & \\
\hline V12 & 0.050340 & 0.164070 & 0.656937 & \\
\hline V13 & 0.278135 & 0.264835 & 0.695385 & \\
\hline V14 & 0.083041 & 0.116575 & 0.681780 & \\
\hline
\end{tabular}

Table 4. Input Correlation Matrix

\begin{tabular}{|c|c|c|c|c|c|c|c|c|c|c|}
\hline & \multicolumn{10}{|c|}{ Input Correlation Matrix } \\
\hline & $\begin{array}{c}1 \\
\text { SS }\end{array}$ & $\begin{array}{l}2 \\
\mathrm{C}\end{array}$ & $\begin{array}{l}3 \\
T\end{array}$ & $\begin{array}{c}4 \\
\mathrm{SP}\end{array}$ & $\begin{array}{c}5 \\
\mathrm{CF}\end{array}$ & $\begin{array}{c}6 \\
\mathrm{PL}\end{array}$ & $\begin{array}{c}7 \\
\text { MKT }\end{array}$ & $\begin{array}{c}8 \\
\text { FIN }\end{array}$ & $\begin{array}{c}9 \\
\mathrm{OP}\end{array}$ & $\begin{array}{c}10 \\
\text { Reliability }\end{array}$ \\
\hline IIS SS & 1 & & & & & & & & & 0.78 \\
\hline C & 0.62 & 1 & & & & & & & & 0.64 \\
\hline $\mathrm{T}$ & 0.59 & 0.52 & 1 & & & & & & & 0.89 \\
\hline $\mathrm{SCl} \mathrm{SP}$ & 0 & 0 & 0 & 1 & & & & & & 0.72 \\
\hline $\mathrm{CF}$ & 0 & 0 & 0 & 0.67 & 1 & & & & & 0.61 \\
\hline PS & 0 & 0 & 0 & 0.72 & 0.53 & 1 & & & & 0.83 \\
\hline FP $\quad$ MKT & 0 & 0 & 0 & 0 & 0 & 0 & 1 & & & 0.75 \\
\hline FIN & 0 & 0 & 0 & 0 & 0 & 0 & 0.59 & 1 & & 0.64 \\
\hline $\mathrm{OP}$ & 0 & 0 & 0 & 0 & 0 & 0 & 0.71 & 0.62 & 1 & 0.81 \\
\hline Means & 3.76 & 3.69 & 3.01 & 4.18 & 3.96 & 4.23 & 3.89 & 4.21 & 3.74 & \\
\hline Std.Dev. & 0.73 & 0.69 & 0.64 & 0.79 & 0.55 & 0.72 & 0.81 & 0.63 & 0.71 & \\
\hline No.Cases & 212 & & & & & & & & & \\
\hline Matrix & 1 & & & & & & & & & \\
\hline
\end{tabular}


Table 5. Model Estimates: Interrelationship between IIS, SCl and FP (Structural Equation-IIS leads to FP with SCI platform)

\begin{tabular}{||l|r|r|r|r|r|}
\hline & \multicolumn{3}{|c|}{ Table: Model Estimates for Interrelationship between IIS, SCl \& FP } \\
\cline { 2 - 6 } & $\begin{array}{c}\text { Parameter } \\
\text { Estimate }\end{array}$ & $\begin{array}{c}\text { Standard } \\
\text { Error }\end{array}$ & \multicolumn{1}{c|}{$\begin{array}{c}\text { T } \\
\text { Statistic }\end{array}$} & $\begin{array}{c}\text { Prob. } \\
\text { Level }\end{array}$ \\
\hline (IIS)-1->[SS] & 0.612 & 0.049 & 12.603 & 0.003 \\
\hline (IIS)-2->[C] & 0.510 & 0.046 & 11.022 & 0.007 \\
\hline (IIS)-3-> T] & 0.450 & 0.043 & 10.462 & 0.002 \\
\hline (DELTA1)-4-(DELTA1) & 0.158 & 0.036 & 4.348 & 0.020 \\
\hline (DELTA2)-5-(DELTA2) & 0.216 & 0.031 & 6.955 & 0.006 \\
\hline (DELTA3)-6-(DELTA3) & 0.207 & 0.027 & 7.697 & 0.009 \\
\hline (SCI)->[SP] & 0.307 & 0.047 & 6.578 & 0.032 \\
\hline (SCl)-7->[CF] & 0.512 & 0.050 & 10.330 & 0.043 \\
\hline (SCI)-8->[PL] & 0.721 & 0.065 & 11.036 & 0.008 \\
\hline (FP)->[MKT] & 0.829 & 0.073 & 10.926 & 0.004 \\
\hline (FP)-9->[FIN] & 0.679 & 0.065 & 10.525 & 0.002 \\
\hline (FP)-10->[OP] & 0.921 & 0.080 & 11.511 & 0.006 \\
\hline (EPSILON1)-11-(EPSILON1) & 0.056 & 0.039 & 1.454 & 0.146 \\
\hline (EPSILON2)-12-(EPSILON2) & 0.153 & 0.018 & 8.527 & 0.003 \\
\hline (EPSILON3)-13-(EPSILON3) & 0.223 & 0.029 & 7.585 & 0.008 \\
\hline (EPSILON4)-14-(EPSILON4) & 0.213 & 0.036 & 5.902 & 0.039 \\
\hline (EPSILON5)-15-(EPSILON5) & 0.192 & 0.023 & 8.309 & 0.007 \\
\hline (EPSILON6)-16-(EPSILON6) & 0.128 & 0.028 & 4.576 & 0.000 \\
\hline (ZETA1)-17-(ZETA1) & 0.568 & 0.072 & 7.940 & 0.003 \\
\hline (ZETA2)-18-(ZETA2) & 0.443 & 0.067 & 6.592 & 0.000 \\
\hline (IIS)-19->(SCl) & 0.611 & 0.060 & 3.010 & 0.004 \\
\hline (IIS)-20->(FP) & 0.364 & 0.055 & 2.010 & 0.008 \\
\hline (SCl)-21->(FP) & 0.463 & 0.068 & 2.570 & 0.004 \\
\hline
\end{tabular}

Table 6. Summary Statistics: Structural Equation-IIS leads to FP with SCI platform

\begin{tabular}{||l|r|}
\hline \multirow{2}{*}{} & \multicolumn{1}{|c|}{ Value } \\
\cline { 2 - 2 } & \multicolumn{1}{|c|}{ Vasic Summary Statistics } \\
\hline Discrepancy Function & 0.00680000000000000 \\
\hline Maximum Residual Cosine & 0.36850717126851390 \\
\hline Maximum Absolute Gradient & 0.00000000000000025 \\
\hline ICSF Criterion & -0.00000000000000011 \\
\hline ICS Criterion & 0.00000000000000056 \\
\hline ML Chi-Square & 0.00000000000037481 \\
\hline Degrees of Freedom & 24.00000000000000000 \\
\hline p-value & 0.27890000000000009 \\
\hline RMS Standardized Residual & 0.00180000000000000 \\
\hline
\end{tabular}




\begin{tabular}{|c|}
\hline (IIS)-1->[SS] \\
(IIS)--->[C] \\
(IIS)-3->[T] \\
(SCI)-->[SP] \\
(SCI)-7->[CF] \\
(SCI)-8->[PL] \\
(FP)-->[MKT] \\
(FP)-9->[FIN] \\
(FP)-10->[OP] \\
(EPSILON1)-->[SP] \\
(EPSILON2)-->[CF] \\
(EPSILON3)-->[PL] \\
(EPSILON4)-->[MKT] \\
(EPSILON5)-->[FIN] \\
(EPSILON6)-->[OP] \\
(EPSILON1)-11-(EPSILON1) \\
(EPSILON2)-12-(EPSILON2) \\
(EPSILON3)-13-(EPSILON3) \\
(EPSILON4)-14-(EPSILON4) \\
(EPSILON5)-15-(EPSILON5) \\
(EPSILON6)-16-(EPSILON6) \\
(ZETA1)-->(SCI) \\
(ZETA2)-->(FP) \\
(ZETA1)-17-(ZETA1) \\
(ZETA2)-18-(ZETA2) \\
(IIS)-19->(SCI) \\
(IIS)-20->(FP) \\
(SCI)-21->(FP) \\
\hline
\end{tabular}

Figure 2. Model Syntax in STATISTICA

\section{Appendix-B}

Table 7. Demographic Data for 212 Respondents

\begin{tabular}{|c|c|c|c|c|}
\hline Variables & Variables & $\begin{array}{c}\text { Total responses } \\
\text { (Freq. with \%) }\end{array}$ & $\begin{array}{c}\text { First-Lot } \\
\text { (Freq. with \%) }\end{array}$ & $\begin{array}{c}\text { Second/ Final Lot } \\
\text { (Freq. with \%) }\end{array}$ \\
\hline No. of employees & $100-250$ & $44(20.75 \%)$ & $18(15.38 \%)$ & $26(27.36 \%)$ \\
\hline & $251-500$ & $76(35.84 \%)$ & $46(39.31 \%)$ & $30(31.57 \%)$ \\
\hline & $501-1000$ & $56(26.41 \%)$ & $36(30.76 \%)$ & $20(21.05 \%)$ \\
\hline Sales in Crores & 1000 and above & $36(16.98 \%)$ & $17(14.52 \%)$ & $19(20.00 \%)$ \\
\hline & Upto. 10 Crores & $09(4.24 \%)$ & $06(3.89 \%)$ & $03(5.17 \%)$ \\
\hline & $10-25$ Crores & $46(21.69 \%)$ & $35(22.72 \%)$ & $11(18.96 \%)$ \\
\hline & $26-100$ Crores & $35(16.50 \%)$ & $23(14.93 \%)$ & $12(20.68 \%)$ \\
\hline & $100-500$ Crores & $92(43.39 \%)$ & $73(47.40 \%)$ & $19(32.75 \%)$ \\
\hline & Over 500 Crores & $30(14.15 \%)$ & $17(11.03 \%)$ & $13(22.41 \%)$ \\
\hline & CEO/President & $13(6.13 \%)$ & $08(5.36 \%)$ & $05(7.93 \%)$ \\
\hline & Director & $23(10.84 \%)$ & $11(7.38 \%)$ & $12(19.04 \%)$ \\
\hline & Manager ( Sr.) & $65(30.66 \%)$ & $48(32.21 \%)$ & $17(26.98 \%)$ \\
\hline & Manager (Mid.) & $82(38.67 \%)$ & $61(40.93 \%)$ & $21(33.33 \%)$ \\
\hline & Others & $29(13.67 \%)$ & $21(14.09 \%)$ & $08(12.69 \%)$ \\
\hline & 0-2 years & $23(10.84 \%)$ & $13(10.40 \%)$ & $10(11.49 \%)$ \\
\hline
\end{tabular}




\begin{tabular}{|l|c|c|c|c|}
\hline & $10-20$ years & $62(29.24 \%)$ & $39(31.20 \%)$ & $23(26.43 \%)$ \\
\hline & $20+$ years & $34(16.03 \%)$ & $20(16.00 \%)$ & $14(16.09 \%)$ \\
\hline
\end{tabular}

Table 8. Variables-Constructs-Survey Items

\begin{tabular}{|c|c|c|}
\hline Variables & Constructs & Survey Items \\
\hline $\begin{array}{l}\text { Information Intensive } \\
\text { Services (IIS) }\end{array}$ & IIS/RP(SS) & $\begin{array}{c}\text { MRP, MRP-II, Enterprise Resource Planning, Advanced Planning System, Decision } \\
\text { Support System, E-procurement. }\end{array}$ \\
\hline- & IIS/ Comm. & $\begin{array}{l}\text { Electronic Data Interchange, Electronic Fund Transfer, Intranet, Internet, E-business, } \\
\text { E-Commerce. }\end{array}$ \\
\hline- & IIS/Track. & $\begin{array}{l}\text { Radio frequency Identification, Barcoding, Inventory Management, Global Positioning } \\
\text { System, Warehouse Management System. }\end{array}$ \\
\hline Supply Chain Integration (SCI) & $\mathrm{SCl} / \mathrm{SP}$ & In sourcing, Outsourcing \\
\hline- & $\mathrm{SCl} / \mathrm{CF}$ & $\begin{array}{c}\text { Systematic IS Integration, Data Integration among internal functions through network, } \\
\text { Data integration in Production Process, Real time searching of the level of Logistics, } \\
\text { Real time searching of the level of Inventory. }\end{array}$ \\
\hline- & $\mathrm{SCl} / \mathrm{PL}$ & $\begin{array}{l}\text { With 3rd Party Logistics (3PL), With Suppliers, With Customers, With Suppliers' suppli- } \\
\text { er, With Customers' customer. }\end{array}$ \\
\hline $\begin{array}{l}\text { Firm Performance } \\
\qquad \text { (FP) }\end{array}$ & FP/Mktg. & $\begin{array}{c}\text { Market Share, Market Performance, Growth of Market Share, Growth of Sales, Cus- } \\
\text { tomer Satisfaction. }\end{array}$ \\
\hline- & FP/Op. & Product Design, Product Quality, Product Delivery, Capacity Utilization, Product Cost. \\
\hline- & FP/Fin. & $\begin{array}{c}\text { Return on Investment, Growth of Return on Investment, Inventory Turnover, Profit } \\
\text { Margin on Sales. }\end{array}$ \\
\hline
\end{tabular}

Table 9. Checking Ideal Survey Attributes (Malhotra and Grover, 1998)

Research Type: Explanatory and Cross Sectional

\begin{tabular}{|c|c|}
\hline Attributes & Yes/No \\
\hline Are multi-item variables used in this research? & yes \\
\hline Is Content validity assessed? & yes \\
\hline Is field-based Pretesting of measures performed? & yes \\
\hline Is Reliability assessed with the analytics? & yes \\
\hline Is Pilot data used for purifying measures? & yes \\
\hline Are Confirmatory method used in this study? & yes \\
\hline Is sample frame defined and justified properly? & justified \\
\hline Is random sampling used from the sampling frame? & yes \\
\hline Is response rate is over 20 percent in the data collection? & Over 20\% \\
\hline Is non-response bias estimated? & No \\
\hline
\end{tabular}




\begin{tabular}{|l|c|}
\hline Are attempts made to establish internal validity of the findings? & yes \\
\hline Is there sufficient statistical power to reduce conclusion error? & partly \\
\hline
\end{tabular}

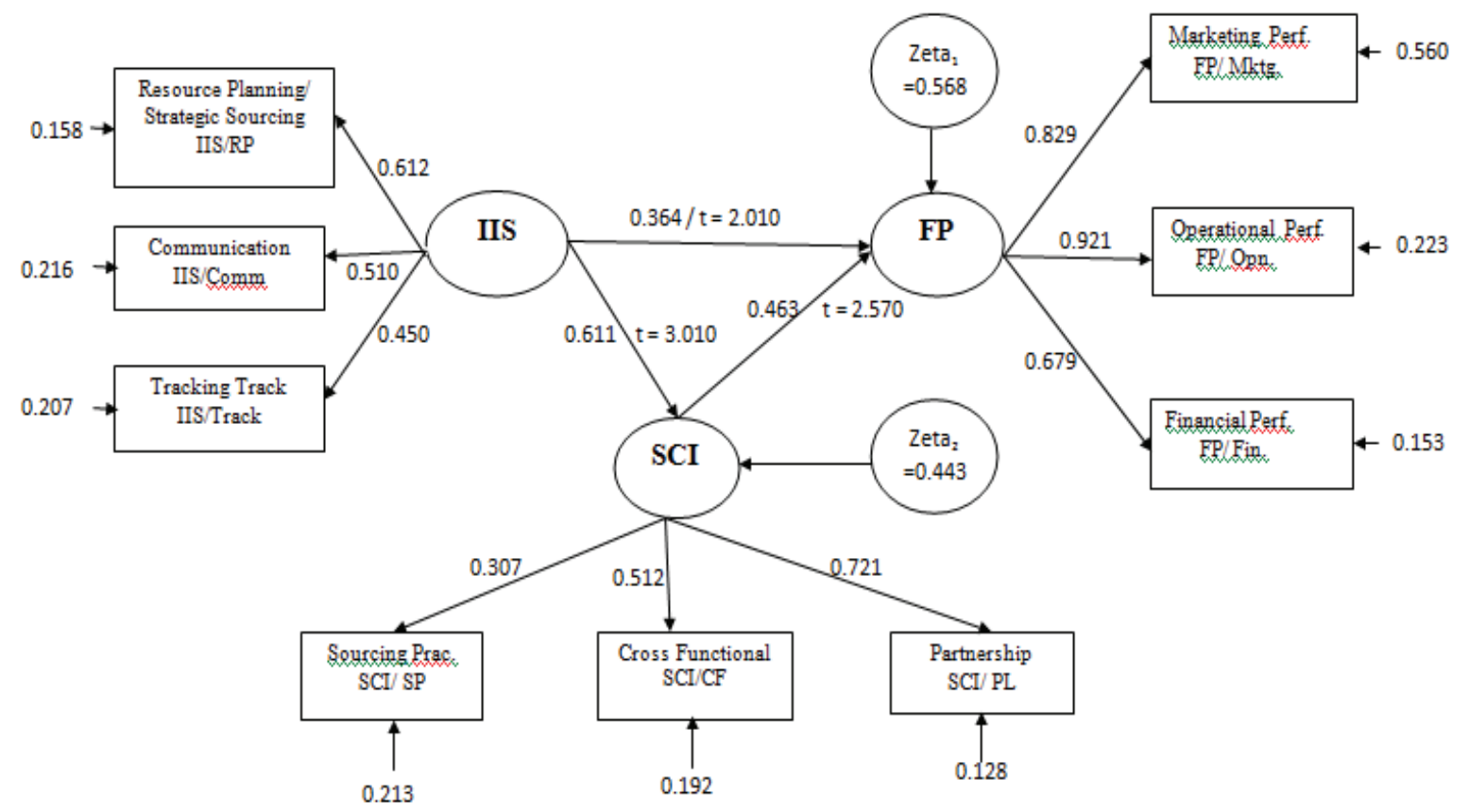

Figure 3. Final Survey Result

Received: 26 Nov 2018

Approved: 11 Mar 2019

DOI: 10.14488/BJOPM.2019.v16.n2.a7

How to cite: Roy, S.; Satpathy, B. (2019), "Strategic alliance between information intensive services and supply chain integration: impact on firm performance", Brazilian Journal of Operations \& Production Management, Vol. 16, No. 2, pp. 241-260, available from: https://bjopm.emnuvens.com.br/bjopm/article/view/647 (access year month day). 